\title{
Hubungan Antara Metode Pelatihan Dengan Kreativitas Peserta Pelatihan Tata Rias Pengantin Di LKP Hermin Jepara
}

\author{
Selly Irfiana Safitri, Niswatul Imsiyah, Lutfi Ariefianto \\ Pendidikan Studi Pendidikan Luar Sekolah, Universitas Jember. Jl. Kalimantan No. 37, Jember 62811, \\ Indonesia \\ Email: shely_aprilio@yahoo.com, niswatul@unej.ac.id, lutfipls.fkip@unej.ac.id,
}

\begin{abstract}
Abstrak
Salah satu peran metode pembelajaran dalam kegiatan belajar mengajar adalah membantu menarik perhatian peserta didik sehingga membangkitan minat motivasi, aktifitas dan kreativitas belajar peserta didik. Kreativitas merupakan hasil belajar dalam kecakapan kognitif, sehingga untuk menjadi kreatif dapat dipelajari melalui proses belajar mengajar. Pada penelitian ini peneliti menentukan indikator berdasarkan dalam 4-P Kreativitas yaitu pribadi (person), pendorong (press), proses (process) dan produk (product). Jenis penelitian yang digunakan adalah korelasi dengan pendekatan kuantitatif. Teknik pengumpulan data menggunakan angket, dokumentasi dan observasi sebagai metode tambahan. Kemudian dianalisis menggunakan rumus korelasi tata jenjang yang dibantu dengan menggunakan alat bantu SPSS versi 24. Berdasarkan hasil perhitungan, diperoleh besar peran (R) sebesar 0,904 (dengan $\mathrm{N}=18$ dan signifikasi 0,000) termasuk dalam kategori korelasi sangat tinggi, jika di prosentasekan diperoleh nilai sebesar $81,72 \%$. Hal ini berarti bahwa terdapat hubungan antara metode pelatihan dengan kreativitas peserta pelatihan tata rias pengantin di LKP Hermin Jepara.
\end{abstract}

Kata Kunci: Metode Pelatihan, Kreativitas, Pelatihan Tata Rias.

\section{The Relationship Between Training Methods and Creativity of Bridal Makeup Training Participants in LKP Hermin Jepara}

\begin{abstract}
One of the roles of learning methods in teaching and learning activities is to help attract the attention of students so as to generate interest in students' motivation, activities and learning creativity. Creativity is the result of learning in cognitive skills, so to be creative can be learned through the teaching and learning process. In this study the researcher determined indicators based on 4-P Creativity, namely person, press, process and product. The type of research used is hierarchical correlation with a quantitative approach. Data collection techniques use questionnaires, documentation and observation as additional methods. The type of research used is a correlation with a quantitative approach. Data collection techniques use questionnaires, documentation and observation as additional methods. Then analyzed using a hierarchical correlation formula which is assisted by using version 24 SPSS tools. Based on the results of calculations, the role $(R)$ is obtained at 0.904 (with $N=18$ and significance 0,000) included in the correlation category very high, if the percentage is obtained a value of $81.72 \%$. This means that there is a relationship between the training method and the creativity of the bridal makeup trainees at LKP Hermin Jepara.
\end{abstract}

Keywords: Training Method, Creativity, Bridal make Up Training. 


\section{Learning Community: Jurnal Pendidikan Luar Sekolah, 3 (2) September 2019 - 15 Selly Irfiana Safitri}

\section{PENDAHULUAN}

Lembaga Kursus dan Pelatihan (LKP) Hermin merupakan salah satu lembaga kursus dan pelatihan yang telah bekerjasama dengan pemerintah Kabupaten Jepara dalam menyelenggarakan berbagai kursus dan pelatihan untuk masyarakat di Kabupaten Jepara. Tata rias pengantin merupakan salah satu kursus yang di selenggarakan oleh Lembaga Kursus dan Pelatihan (LKP) Hermin Jepara dengan jumlah peserta yang mengikuti kursus dan pelatihan sebanyak 18 orang yang memiliki kesenjangan daya serap dalam menerima materi yang disampaikan oleh pendidik atau tutor dan cenderung menerima apa yang disampaikan oleh pendidik atau tutor serta tidak mau berfikir untuk memiliki ciri khas dan kreativitas dalam riasannya, sehingga hasil riasan dari peserta pelatihan pun masih monoton kurang menarik, kreatif dan inovatif serta cenderung kuno. Sama halnya pembelajaran, dalam pelatihan metode pembelajaran berarti langkah atau rancangan yang terstruktur dan terencana, sesuai tujuan yang ingin dicapai dalam pendidikan (Faizi, 2013:21). Kreativitas merupakan hasil belajar dalam kecakapan kognitif, sehingga untuk menjadi kreatif dapat dipelajari melalui proses belajar mengajar (Slameto, 2010:138).

Berdasarkan latar belakang diatas, maka rumusan masalah pada penelitian ini adalah adakah hubungan antara metode pelatihan dengan kreativitas peserta pelatihan tata rias di LKP Hermin Jepara?". Tujuan dalam penelitian ini untuk mengetahui hubungan antara metode pelatihan dengan kreativitas peserta pelatihan tata rias di LKP Hermin Jepara. Hasil penelitian ini diharapkan menjadi salah satu pengaplikasian materi yang sudah didapatkan peneliti di perkuliahan, serta dapat dijadikan bahan evaluasi dalam meningkatkan kemampuan lulusan sebuah program pelatihan yang akan dilaksanakan kelak.

\section{METODE}

Jenis penelitian yang digunakan adalah penelitian korelasional dengan pendekatan kuantitatif. Teknik analisis data yang digunakan adalah korelasi tata jenjang. Lokasi penentuan tempat yaitu Purposive
Area. Teknik penentuan responden menggunakan teknik populasi. Waktu yang digunakan dalam penelitian ini adalah 6 bulan. Metode pengumpulan data dilakukan dengan penyebaran angket, dokumentasi serta observasi sebagai pengumpulan data tambahan. Hasil dari pengisian lembar angket yang sudah dibagikan kepada responden yaitu peserta pelatihan LKP Hermin yang berjumlah 18 orang dimana dalam setiap angket terdiri dari 12 butir pernyataan, selanjutnya akan dilakukan proses editing, coding dan scoring. Apabila keseluruhan item pernyataan sudah terisi, maka akan dilakukan analisis data lebih lanjut dengan menggunakan rumus korelasi tata jenjang yang diolah dengan SPSS (Stasstitical Package for the Social Sciences) versi 24.

\section{HASIL DAN PEMBAHASAN}

Adapun hasil perhitungan menunjukkan hasil hubungan antara metode pelatihan dengan kreativitas diperoleh $\mathrm{r}_{\text {hitung }}$ sebesar 0,904 dengan $\mathrm{N}=18$ jika dikonsultasikan dengan harga $r_{\text {tabel }}$ sebesar 0,506 pada taraf kepercayaan 95\% menunjukkan bahwa $r_{\text {hitung }}$ lebih besar dari $r_{\text {tabel. }}$ Sedangkan hasil perhitungan keduanya dipresentasikan, menunjukkan bahwa kreativitas peserta pelatihan mendapat kontribusi melalui metode pelatihan sebesar $81,72 \%$ terhadap kreativitas dalam hal pribadi, pendorong, proses dan produk. Sedangkan sisanya 18,28\% dipengaruhi oleh faktor lain. Berdasarkan indikator yang dijadikan pengukuran, diketahui bahwa indikator ceramah memberikan kontribusi dalam kategori tinggi yaitu sebesar 0,776 atau $60,21 \%$ terhadap kreativitas peserta pelatihan. Selanjutnya indikator praktek memberikan kontribusi dalam kategori yang sangat tinggi yaitu sebesar 0,870 atau $75,69 \%$ terhadap kreativitas peserta pelatihan. Dengan demikian dapat disimpulkan bahwa metode pelatihan memiliki hubungan yang sangat tinggi dengan kreativitas peserta pelatihan tata rias pengantin di Kabupaten Jepara. Hal ini menunjukkan bahwa ketepatan tutor dalam menggunakan metode dalam kegiatan pelatihan mempengaruhi kreativitas peserta pelatihan.

Berdasarkan analisis data tersebut, bahwa terdapat hubungan yang sangat tinggi 


\section{Learning Community: Jurnal Pendidikan Luar Sekolah, 3 (2) September 2019 - 16}

Selly Irfiana Safitri

antara metode pelatihan dengan kreativitas peserta pelatihan tata rias pengantin di Kabupaten Jepara. Hal tersebut diperoleh dari perhitungan data menggunakan SPSS (Statistical Product And Service Solution) versi 24. Dengan demikian, (Ho) ditolak dan ( $\mathrm{Ha})$ diterima, artinya bahwa metode pelatihan memberikan kontribusi terhadap kreativitas peserta pelatihan tata rias pengantin di Kabupaten Jepara. Kedudukan metode adalah sebagai alat motivasi ekstrinsik, sebagai strategi pengajaran dan juga sebagai alat untuk mencapai tujuan (Djamarah dan Zain, 2010:72). Salah satu peran metode pembelajaran dalam kegiatan belajar mengajar adalah membantu menarik perhatian peserta didik sehingga membangkitan minat motivasi, aktifitas dan kreativitas belajar peserta didik (Aqil, Murtadlo, 2016:6). Penggunaan metode pelatihan yang tepat akan menunjang pemahaman peserta pelatihan yang akan memicu ide-ide yang baru, menarik, kreatif yang bermanfaat bagi riasannya kelak. Sehinga peserta didik mampu mengikuti trend-trend rias seiring dengan perkembangan zaman.

Sedangkan untuk analisis masingmasing indikator adalah : untuk indikator ceramah terhadap kreativitas termasuk dalam kategori tinggi. Ceramah adalah penuturan bahan pelajaran secara lisan. Metode ini tidak senantiasa jelek bila penggunaannya dipersiapkan dengan baik, didukung dengan alat dan media, serta memperhatikan batas-batas penggunaannya. Komunikasi pada Metode ini bisa dilengkapi dengan audio visual, tanya jawab, diskusi dan sebagainya (Sudjana, 2000:77. Penggunaan metode ceramah dalam proses belajarmengajar haruslah didasarkan pada kapan metode ini tepat digunakan (Soetomo, 1993:147). Penggunaan metode ceramah juga harus disesuaikan dengan situasi dan kondisi yang tepat agar tujuan dalam pelatihan berupa kreativitas juga tercapai. Tingginya tingkat korelasi menunjukkan bahwa metode ceramah berdampak positif terhadap kreativitas peserta, ini dapat dilihat dari peserta pelatihan yang mampu untuk menyelesaikan tugas dan "think out of the box", memiliki keinginan untuk dapat menjadi yang terbaik, mererima materi yang disampaikan dengan baik, suasana belajar yang kondusif dengan bertukar pendapat saat proses pembelajaran serta menuangkan ideide saat proses pembelajaran.

Untuk indikator praktek terhadap kreativitas termasuk dalam kategori yang sangat tinggi, bahwa metode ini memberikan jalan kepada para peserta untuk menerapakan, menguji dan menyesuaikan teori dengan kondisi sesungguhnya melalui paktik atau kerja, inilah peserta praktik atau latihan akan mendapatkan pelajaran yang sangat baik untuk mengembangkan dan menyempurnakan keterampilan yang di perlukan Simanjuntak (1983:29). Tingginya tingkat korelasi menunjukkan bahwa metode praktek berdampak positif terhadap kreativitas peserta, ini dapat dilihat dari peserta pelatihan yang mampu menunjukkan bakat dalam kelancaran saat proses pembelajaran, memperagakan setiap materi yang telah disampaikan oleh tutor dengan baik, benar dan tidak gugup, mampu menciptakan hal-hal baru, mampu menunjukkan bakat atau ide-ide baru yang dipmiliki, mampu menggabungkan hasil inovasi dengan hal-hal yang sudah lama.

\section{SIMPULAN}

Berdasarkan analisis data maka dapat disimpulkan bahwa terdapat hubungan dengan kategori korelasi yang sangat tinggi antara metode pelatihan dengan kreativitas peserta pelatihan tata rias di LKP Hermin Jepara. Saran dari penelitian ini yaitu untuk pengelola hendaknya lebih meningkatkan kualitas dan melengkapi sarana dan prasarana yang digunakan dalam pelatihan, sehingga dapat meningkatkan kreativitas merias peserta pelatihan. Bagi peneliti lain hendaknya melakukan penelitian lanjutan hal-hal lain yang dapat meningkatkan kreativitas peserta pelatihan tata rias pengantin di Lembaga Kursus dan Pelatihan (LKP) Hermin Kabupaten Jepara.

\section{DAFTAR PUSTAKA}

Aqil, Z \& Murtadlo, 2016. Kumpulan metode pembelajaran. Bandung: PT Sarana Tutorial Nurani Sejahtera.

Djamarah dan Zain. 2010. Strategi Belajar Mengajar.Jakarta: Rineka Cipta.

Djudju, Sudjana. 2000. Strategi Pembelajaran Pendidikan Luar Sekolah. Bandung: Nusantara Press. 
Learning Community: Jurnal Pendidikan Luar Sekolah, 3 (2) September 2019 - 17 Selly Irfiana Safitri

Faizi, M. 2013. Ragam Metode Mengajarkan

Eksakta pada Murid. Jogjakarta: Diva Press

Faizi, M. 2013. Ragam Metode Mengajarkan Eksakta pada Murid. Jogjakarta: Diva Press

Simanjuntak. 1983. Proses Belajar Mengajar. Bandung: PT Tarsito

Slameto. 2010. Belajar dan Faktor-faktor yang Mempengaruhinya. Jakarta: PT. Rineka Cipta.

Soetomo. 1993. Dasar-Dasar Interaksi Belajar Mengajar. Surabaya: Usaha Nasional. 